Martin, E. C., P. F. Doherty, Jr., K. A. Jochum, and C. F. Bagley. 2022. Abundance and habitat use estimates show Lesser Yellowlegs (Tringa flavipes) breed in high numbers in interior Alaska. Avian Conservation and Ecology 17(1):8. https://doi.org/10.5751/ACE-02012-170108 Copyright (C) 2022 by the author(s). Published here under license by the Resilience Alliance.

Research Paper

\title{
Abundance and habitat use estimates show Lesser Yellowlegs (Tringa flavipes) breed in high numbers in interior Alaska
}

\author{
Ellen C. Martin ${ }^{1}$, Paul F. Doherty, Jr. ${ }^{1}$, Kim A. Jochum ${ }^{2}$ and Calvin F. Bagley ${ }^{2}$ \\ ${ }^{1}$ Department of Fish, Wildlife, and Conservation Biology, Colorado State University, ${ }^{2}$ Center for Environmental Management of \\ Military Lands, Colorado State University
}

\begin{abstract}
Lesser Yellowlegs (Tringa flavipes) abundance has declined by approximately 75\% across North America since 1970 . Despite this dramatic decline, Lesser Yellowlegs are infrequently studied on their breeding grounds and have rarely been studied in the boreal forest of Alaska where population size is uncertain. We used a spatially balanced sampling design and surveyed 400 by $400 \mathrm{~m}$ plots in 2016 and 2017 to (1) estimate abundance and habitat use of Lesser Yellowlegs breeding on military lands in interior Alaska, and (2) test hypotheses about which habitat covariates best explain variation in plot abundances and habitat use. We predicted that boreal forest habitats on military lands in central Alaska supported a large percent of breeding Lesser Yellowlegs and that plots containing water and situated closer to wetlands would have the highest abundances compared to other habitat variables tested. We also predicted that increased presence of lowland habitat and associated vegetation covariates (e.g., percent low scrub canopy) increased probability of habitat use. In 2017, Lesser Yellowlegs abundance at the study site was 12,478 individuals, and habitat use was negatively associated with increasing elevation and percent canopy cover on plot. We estimate that military lands in interior Alaska support $8 \%$ of all Lesser Yellowlegs breeding in Alaska. Therefore, studies identifying important Lesser Yellowlegs breeding habitat and addressing conservation priorities in the boreal forest should be continued.
\end{abstract}

\section{Les estimations de population et d'utilisation de l'habitat indiquent que les Petits Chevaliers (Tringa flavipes) se reproduisent en grand nombre dans l'intérieur des terres de l'Alaska}

RESUME_. La population de petits chevaliers (Tringa flavipes) a baissé d'environ $75 \%$ en Amérique du Nord depuis 1970 . Malgré ce déclin spectaculaire, les petits chevaliers sont rarement étudiés sur leurs territoires de reproduction et ont rarement fait l'objet d'études dans la forêt boréale d'Alaska, où l'importance de leur population est incertaine. Nous avons utilisé un modèle d'échantillonnage équilibré dans l'espace et observé des parcelles de 400 x 400 mètres en 2017 afin (1) d'estimer l'abondance et l'utilisation de l'habitat par les petits chevaliers qui se reproduisent sur les terrains militaires à l'intérieur de l'Alaska, et (2) de tester des hypothèses concernant les covariables de l'habitat qui expliquent le mieux les variations en termes d'abondance sur les parcelles et d'utilisation de l'habitat. Nous avions prédit que les habitats de la forêt boréale situés sur des terrains militaires du centre de l'Alaska accueillaient un fort pourcentage de petits chevaliers pendant la période de reproduction et que les parcelles contenant de l'eau et plus proches des terrains marécageux abritaient des populations plus nombreuses que les autres variables d'habitat étudiées. Nous pensions également que la présence accrue de covariables d'habitats de basse terre et de végétation associée (par ex. le pourcentage d'arbustes) augmentait la probabilité d'utilisation de l'habitat. En 2017, nous avions dénombré une population de 12478 petits chevaliers sur le site de l'étude et l'utilisation de l'habitat était inférieurement proportionnelle à l'altitude croissante et au pourcentage de couverture de canopée sur les parcelles. Nous estimons que les terrains militaires de l'intérieur de l'Alaska abritent $8 \%$ de l'ensemble de la population de petits chevaliers qui se reproduisent en Alaska. En conséquence, les études identifiant l'habitat de reproduction majeur des petits chevaliers et traitant des priorités de conservation dans la forêt boréale devraient être poursuivies.

Key Words: abundance estimation; Alaska; conservation; habitat use; Lesser Yellowlegs; PRISM survey; shorebird

\section{INTRODUCTION}

Lesser Yellowlegs (Tringa flavipes) is listed as a species of high conservation concern by the U.S. Fish and Wildlife Service (USSCPP 2016) and listed as a species of high concern by the Alaska shorebird conservation plan (Alaska Shorebird Group 2019). Current abundance estimates for Lesser Yellowlegs have low certainty and are derived from a mix of expert opinion and aerial surveys (Andres et al. 2012). North American abundance estimates range from 400,000 (Morrison et al. 2006) to 660,000 individuals (Andres et al. 2012, Alaska Shorebird Group 2019), with $24 \%$ of those estimated to breed in interior Alaska boreal forest (96,000-158,400 Lesser Yellowlegs; Andres et al. 2012, Alaska Shorebird Group. 2019). These continental population estimates are uncertain, and in general, have increased over time as new data have been added (Andres et al. 2016). However, accurate and adequate information about continental population sizes is still lacking (Clay et al. 2012), resulting in great uncertainty about the conservation status of this species.

Population trend estimates of Lesser Yellowlegs show that the species has experienced a decline of approximately $75-90 \%$ in

Correspondent author: Ellen C. Martin, Department of Fish, Wildlife, and Conservation Biology, Colorado State University, Fort Collins, Colorado 80523;, , Centre for Biodiversity Dynamics, Norwegian University of Science and Technology, Trondheim, Norway 7030, ellen.c.martin@ntnu.no 
North America (Butcher and Niven 2007, Sauer et al. 2011, Clay et al. 2012), with a $2.8 \%$ and $3.2 \%$ annual decline in United States and Canadian breeding bird survey (BBS) routes, respectively, during the period 1970-2016 (Sauer et al. 2020). More locally, a $5.4-9.2 \%$ annual decline in abundance in the northwest interior boreal forest of Alaska was estimated from roadside and off-road surveys (Handel and Sauer 2017). Causes of the declines in Lesser Yellowlegs abundance are unknown, but illegal and sport hunting on migratory stopover sites (Clay et al. 2012, Watts et al. 2015) and decreasing availability of wetland habitat at breeding and migratory stopover sites (Skagen 2006) are believed to be drivers.

Given the uncertainty around absolute abundance estimates, population trajectories, and the associated concern, surprisingly few studies have been conducted on Lesser Yellowlegs' status and trends on their breeding grounds in Bird Conservation Region 4 (BCR 4; Alaska Shorebird Group 2008, Andres et al. 2016). BCR 4 is one of 67 bird conservation regions in North and Central America, which are distinguished from one another by common habitats, conservation management strategies, and common bird communities (see NABCI [date unknown]). BCR 4 is $\sim 722,000$ $\mathrm{km}^{2}$ and spans Alaska and Northwestern Canada interior forest (i.e., boreal forest). From other studies in the Lesser Yellowlegs species range, BCR 4 is known to contain important breeding habitat characteristics (Tibbitts and Moskoff 1999, Clay et al. 2012), i.e., wetlands, dwarf scrub, and open low sedge areas (Elphick and Tibbitts 1998, Tibbitts and Moskoff 1999, Clay et al. 2012). Although abundance and trend estimation have improved with the recent implementation of shorebird monitoring programs and conservation initiatives such as the Program for Regional and International Shorebird Monitoring (PRISM) and the Western Hemisphere Shorebird Reserve Network, indices of local population trends in the boreal forest and basic ecological data such as habitat use remain unknown for Lesser Yellowlegs (Lindström et al. 2015).

Shorebird research needs in the boreal forest were identified by the Alaska shorebird conservation plan (Alaska Shorebird Group 2019) and include designing, assessing, and implementing survey approaches to estimate abundances and identify shorebird use areas, especially for species of conservation concern (Alaska Shorebird Group 2019). To address these research needs, we first investigated overall shorebird abundances across lowland and upland shorebird guilds (Martin et al. 2020). We identified guildwide abundances of breeding shorebirds, regardless of species, and addressed the differences in local abundances to determine if our study site met basic Western Hemisphere Shorebird Reserve Network criteria to be considered a site of importance. Building from that research, species-specific abundance estimation and targeted habitat use investigations can offer unique insights for management of a single species of concern. In this paper, we further address the action items of the Alaska shorebird conservation plan for a species of conservation concern, Lesser Yellowlegs, by disentangling species-specific abundance estimates and habitat use from a larger dataset collected in the interior boreal forest (Martin 2019). These species-specific estimates will inform targeted management efforts for this species of high conservation concern as efforts to address precipitous declines are gaining momentum.
In Alaska, potential breeding areas for Lesser Yellowlegs include Department of Defense (DoD) lands. The DoD manages more than half a million hectares $\left(\sim 5,000 \mathrm{~km}^{2} ; 0.69 \%\right.$ of land area of BCR 4) of interior Alaska boreal forest (Fort Wainwright, Alaska, including Tanana Flats Training Area near Fairbanks, and Donnelly Training Area, near Delta Junction, Alaska) for military training (U.S. Army Garrison Fort Wainwright 2013). The majority of training lands in interior Alaska are remote with no road access and are primarily used for aerial training exercises. Maneuver exercises on the ground are more frequently conducted in road-accessible training lands because of ease of access and other logistical considerations. On these training areas with roads, moderate military and recreational activity occurs year-round, including trapping and hunting as well as brief, but high-intensity, use from military aerial gunnery. The time period of peak military training, maneuver training, and live-fire weapons training coincides with shorebird nest initiation and breeding territory establishment (U.S. Army Garrison Fort Wainwright 2013). Primary impacts to soils, vegetation, and wetlands occur from driving vehicles on- and off-road (U.S. Army Garrison Fort Wainwright 2013), meaning most impacts to the boreal forest on military lands occur within a small radius around the few roads in the training area and those habitats outside this radius remain largely undisturbed. In an effort to maximize military training opportunities while enhancing and protecting biological diversity, the DoD documents species on lands it manages and uses (Center for Environmental Management of Military Lands 1999). Estimating population sizes and habitat use of avian species using military lands is an important step in managing and ensuring protections for these species.

Our objectives were to (1) estimate abundance and habitat use of Lesser Yellowlegs breeding on military lands in interior Alaska and (2) test hypotheses about which habitat covariates best explain variation in abundance and habitat use. Beyond hypothesizing that the boreal forest in military lands in interior Alaska contained important breeding habitat for Lesser Yellowlegs, we predicted that lowland strata on our study site (i.e., Tanana Flats Training Area River and Tanana Flats Training Area Lowlands) would support higher abundances of Lesser Yellowlegs than upland strata because of proximity to nutrient-rich riverine corridors. We predicted that mixed upland strata (i.e., Donnelly Training Area East and Donnelly Training Area West) would have lower abundances of Lesser Yellowlegs because of steep, higher elevation terrain and fewer patches of suspected suitable breeding habitat. We also predicted that use by Lesser Yellowlegs would decrease as shrub percent cover increased, increase as distance to wetland decreased, and increase in wet grassland/open mudflat habitat (Viereck et al. 1992).

\section{METHODS}

\section{Study site}

Fort Wainwright (USAG Alaska) military lands in interior Alaska are composed of several training areas, two of which are Tanana Flats Training Area (TFTA) and Donnelly Training Area (DTA). TFTA spans 258,900 hectares $\left(64^{\circ} 33^{\prime} 5^{\prime \prime} \mathrm{N},-147^{\circ} 44^{\prime} 16^{\prime \prime}\right.$ W) and DTA spans $\sim 267,000$ hectares $\left(64^{\circ} 2^{\prime} 38^{\prime \prime} \mathrm{N},-146^{\circ} 7^{\prime} 32^{\prime \prime} \mathrm{W}\right)$. Together, these training areas contain 94 uniquely identified 
Fig. 1. Study area within Alaska (1a), Tanana Flats Training Area (1b), and Donnelly Training Area (1c).

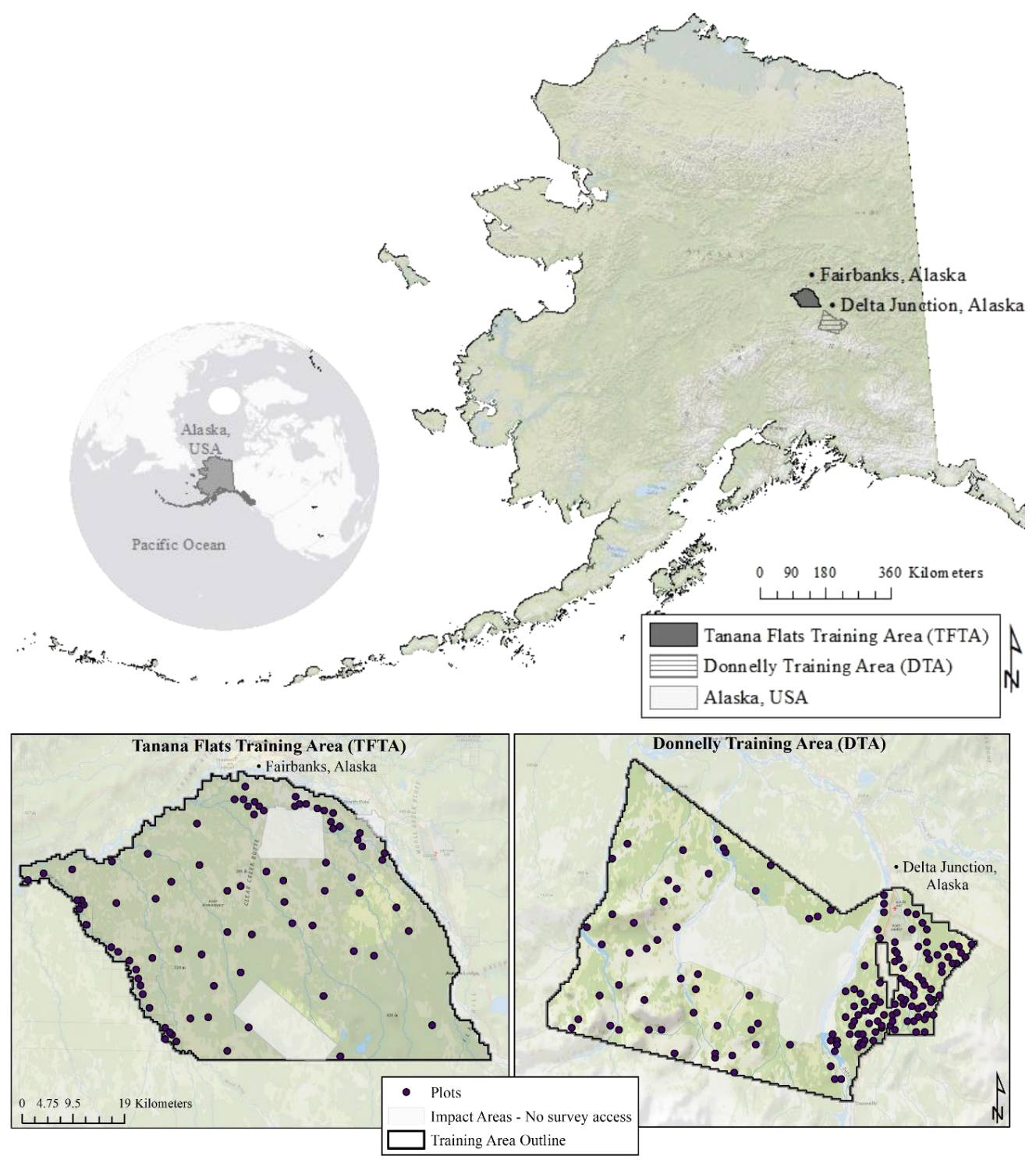

habitat types (Viereck et al. 1993). TFTA is situated south of Fairbanks, Alaska. DTA, split into DTA East and DTA West, is located south-west of Delta Junction, Alaska, and abuts Fort Greely (Fig. 1a). TFTA is a lowland ecosystem $(120-360 \mathrm{~m}$ in elevation), composed of wetland habitats and river corridors (Fig. 1b). Dominant habitat classification in TFTA is characterized by closed boreal forest composed of black spruce (Picea mariana), white spruce (Picea glauca), and aspen (Populus tremuloides), as well as open wetlands composed of sedges, grass, and tussock tundra. DTA is mixed upland and lowland habitat $(>600 \mathrm{~m}$ elevation), with most of the training area composed of habitat classifications characteristic of uplands (Fig. 1c; Viereck et al. 1993, Gallant et al. 1995, Martin et al. 2020). Dominant vegetation on DTA is low scrub (lingonberry [Vaccinium vitisidaea], dwarf birch [Betula nana], bog blueberry [Vaccinium uliginosum]), and ground cover such as moss and lichen. Primary disturbances on our study site are related to military use (U.S. Army Garrison Fort Wainwright 2013).

\section{Sampling design}

The Arctic PRISM program for shorebird monitoring (Bart et al. 2005) served as the model for our survey methods. We designed and implemented a modified Arctic PRISM protocol adjusted for the challenges and needs of conducting surveys in the boreal forest (Martin et al. 2020). PRISM did not recommend one approach to conducting boreal forest shorebird surveys, but instead offered a list of untested survey methods (Skagen et al. 2003). Suggestions included aerial surveys, mini-Breeding Bird Surveys, and an emulation of the Arctic PRISM survey (Skagen et al. 2003). Including a probability-based sampling design to choose survey 
plots and accounting for imperfect detection on surveyed plots are two important, but often overlooked elements in abundance and habitat use survey designs (Nichols et al. 2000, Williams et al. 2002). We used an adjusted Arctic PRISM survey protocol to address the boreal forest survey requirements ensuring a stratified, random design with a spatially balanced sampling tool (Stevens and Olsen 2004, Theobald et al. 2007, ESRI 2011) and incorporated detection estimates using a dependent double observer method (Nichols et al. 2000). We repeatedly visited randomly selected 400 by $400 \mathrm{~m}$ plots within two training areas (TFTA and DTA), separated into four strata (TFTA River, TFTA Lowland, DTA East, and DTA West).

Plot locations were generated independently in the four strata using the spatially balanced sampling tool in ESRI (Stevens and Olsen 2004, Theobald et al. 2007, ESRI 2011). Based on sampling access opportunities, three of the strata had equal sample allocation (TFTA Lowlands, DTA East, and DTA West). The fourth stratum (TFTA River) was sampled at a higher frequency because of ease of accessibility. Plot access was dependent on helicopter scheduling, weather, vehicle availability, and training area closures. We visited selected 400 by $400 \mathrm{~m}$ plots twice within the same year and repeated the visits in the second year. We also doubled the number of plots surveyed in 2017 (142 plots) compared to 2016 (78 plots) to achieve a desirable coefficient of variation.

We used a dependent double-observer survey method on each plot to collect data on presence/absence and number of Lesser Yellowlegs and habitat covariates (Nichols et al. 2000). A primary observer walked ahead of a secondary observer and indicated verbally where shorebirds were observed, species name, and number in each group (defined as shorebirds within $10 \mathrm{~m}$ of each other). The secondary observer recorded the shorebirds observed by the primary observer and any shorebirds that the primary observer missed. The observers walked transects through the entire plot. A plot required six transects to be considered fully surveyed, each transect between 50 and $60 \mathrm{~m}$ apart. Lesser Yellowlegs are ground nesters and flushed at variable distances. At the end of the survey both observers collaboratively collected habitat data within a $50 \mathrm{~m}$ radius of the center of each plot. The team collected data on Viereck classification, average shrub height, shrub and tree cover proportion, open water proportion, and dominant vegetation species. Additionally, a broad vegetation categorization for the entire 16 ha plot was recorded at the end of each survey.

\section{Data analysis: abundance}

In Program MARK (White and Burnham 1999), we derived plotlevel abundance $(\mathrm{N})$ and modeled detection probability (p) using Huggins closed captures models (Huggins 1989, 1991). With the Huggins models, abundance is a derived parameter instead of within the model likelihood, allowing us to model individual covariates on detection. We used data from first visits in 2017 , the year with the most survey effort, and estimated detection using the difference in detected birds between primary observer and secondary observer. This detection is the probability of detecting an individual bird given it is available on a plot. We constructed candidate models representing hypotheses for abundance and detection (Table 1). We examined correlations among all habitat covariates and found none of importance $(r<0.15)$. Preliminary modeling found no difference in detection among observers, likely because of extensive pre-field season training, and thus a covariate for observer difference was not included. We ran goodness-of-fit tests using a median c-hat ( $\hat{c})$ procedure (Cooch and White 2013).

We selected the most parsimonious model from a model set consisting of all possible combinations of habitat covariate models on detection by ranking the models using Akaike's Information Criterion with a small sample size correction $\left(\mathrm{AIC}_{\mathrm{c}}\right.$; Akaike 1974, Burnham and Anderson 2002). We determined relative importance of covariates by summing Akaike weights $\left(w_{i}\right)$ across all models containing a specific variable. The model containing all variables with cumulative $\mathrm{AIC}_{\mathrm{c}}$ weights $\left(w_{i}\right) \geq 0.50$ was used to derive abundance estimates for our study area (Burnham and Anderson 2002, Doherty et al. 2012, Bromaghin et al. 2013). We derived plot-level densities per hectare and then we extrapolated these densities to all surveyable habitat (i.e., sampling frame) for each of the four strata (TFTA River, TFTA Lowlands, DTA East, and DTA West). Variance estimates were calculated following Bowden et al. (2003) to account for detection covariance structures across plots within strata.

To determine the maximum biological process variability possible in our data (White and Burnham 1999), we ran a variance components analysis on the derived abundance estimates from the mean model (i.e., model with no covariates, intercept model) in Program MARK. From this maximum variability, we subtracted the amount of process variance explained by each covariate individually and divided by total process variance to determine the percent of process variability explained by each habitat covariate.

\section{Data analysis: habitat use}

We used occupancy models to estimate shorebird habitat use, colonization, and detection, as well as to correlate predicted habitat covariates to use and detection (Mackenzie et al. 2017). We pooled all presence/absence data from both observers within a visit and estimated occupancy within and between survey years to understand colonization/extinction dynamics. We note that detection in an occupancy model is different from detection in abundance model. Estimated detection in an occupancy model is the probability of detecting a species (one or more individuals) given it is available. We analyzed Lesser Yellowlegs presence/ absence data with a dynamic multi-season (robust design) occupancy model in Program MARK (White and Burnham 1999) that estimates habitat use $(\psi)$, detection $(p)$, colonization $(\gamma)$, and derived extinction $(\varepsilon)$. Colonization $(\gamma)$ and extinction $(\varepsilon)$ were parameters which were included to estimate probability that an unused/used plot in 2016 was subsequently used (colonization) or unused (extinction) in 2017. For the analysis, habitat use was our principal parameter of interest. A priori, we developed and created candidate models to test hypotheses about use, colonization, and detection, and focused on covariates such as elevation, distance to water, shrub cover, and habitat classifications (Table 1). Our hypotheses considered shorebird biology, habitat ecology, and previous literature to represent the likely strongest and highest weighted habitat covariates (e.g., Andres et al. 2012). Habitat use and colonization hypotheses have similar predicted relationships with covariates (Table 1) because literature has shown that there is a relationship between individual 
Table 1. Lesser Yellowlegs (Tringa flavipes) covariate predictions (positive [+], negative [-], or not applicable [NA]) for abundance, habitat use, colonization, and detection. Habitat classifications are from Viereck et al. (1993) and include open forest, tall scrub, low scrub, dwarf scrub, herbaceous (graminoid/forb), moss/lichen, water, and barren ground cover classifications.

\begin{tabular}{|c|c|c|c|c|c|}
\hline Parameter & $\begin{array}{c}\text { Elevation } \\
\text { (meters) }\end{array}$ & $\begin{array}{c}\text { Percent water on } \\
\text { plot } \\
(0-100 \%)\end{array}$ & $\begin{array}{c}\text { Distance to } \\
\text { wetland } \\
(0-5300 \mathrm{~m})\end{array}$ & $\begin{array}{c}\text { Percent shrub } \\
\text { cover } \\
(0-100 \%)\end{array}$ & $\begin{array}{l}\text { Most used/colonized } \\
\text { Viereck Classification }\end{array}$ \\
\hline Abundance & - & + & - & - & $\begin{array}{l}\text { Wet, grassland / } \\
\text { open mudflat }\end{array}$ \\
\hline Detection & + & + & - & + & NA \\
\hline Habitat Use & - & + & - & - & $\begin{array}{l}\text { Wet, grassland / } \\
\text { open mudflat }\end{array}$ \\
\hline Colonization & - & + & - & - & $\begin{array}{c}\text { Wet, grassland / } \\
\text { open mudflat }\end{array}$ \\
\hline
\end{tabular}

decisions and habitat features related to reproductive success (Bled et al. 2011).

Following our methods for abundance estimation, we relied upon $\mathrm{AIC}_{\mathrm{c}}$ for model selection (Burnham and Anderson 2002), but used a two-step process (Lebreton et al. 1992, Doherty et al. 2012). For the first step of model selection on Lesser Yellowlegs, we held use $(\psi)$ and colonization $(\gamma)$ constant (.), where "." indicates an intercept-only model, to estimate effects of all possible additive combinations of predicted habitat covariates and three predicted time effects (visit, year, and visit*year) on detection (p). In subsequent models, we held colonization $(\gamma)$ and detection $(p)$ constant (.) to estimate effects of all possible combinations of predicted habitat covariates plus a year effect on habitat use $(\psi)$. We followed this same pattern for evaluating the full set of predicted covariates on colonization $(\gamma)$. Within a balanced model set for a particular parameter $(\varphi, \gamma, p)$, we summed Akaike model weights (cumulative variable weights: $w_{i}$ ) across all models containing a particular variable to determine relative importance of covariates (Burnham and Anderson 2002). For each parameter $(\varphi, \gamma, \mathrm{p})$, variables or time structures with $w_{i} \geq 0.50$ were retained for the second step of model selection.

The global model we used in step two of model selection included all variables retained for each parameter from step one. From this global model, we constructed all possible additive combinations of variables on all parameters and evaluated both cumulative variable weights and top models in selecting important variables. Following Barbieri and Berger (2004), our predictive model included variables with $w_{i} \geq 0.50$ and our figures are based on this model. We ran goodness-of-fit tests using a median c-hat procedure (Cooch and White 2013). The goodness-of-fit tests helped ensure that the most saturated model in our candidate model set sufficiently fit the data and met model assumptions.

\section{RESULTS}

\section{Raw survey results}

Surveys were initiated on 7 May 2016 and 9 May 2017, and ended 14 July 2016 and 14 July 2017 to align with cessation of breeding and historical shorebird departure from the area (Kessel and Gibson 1978). We surveyed 78 plots in 2016 and 142 plots in 2017. We observed Lesser Yellowlegs on seven plots (8.9\%) in 2016 with
43 individuals observed and on 27 plots $(19 \%)$ in 2017 with 144 individuals observed.

\section{Lesser Yellowlegs abundance estimation results}

We analyzed all possible combinations of habitat covariates on detection (percent scrub on plot, percent water on plot, distance to wetland, forest Viereck classification, scrub Viereck classification, and forb/lichen/herbaceous Viereck classification). The only variable with $w_{i} \geq 0.50$ for detection was percent water on plot (Table 2).

Table 2. Model selection results for Lesser Yellowlegs (Tringa flavipes) models of detection probability (p) and abundance (N). We relied upon Akaike's Information Criterion (with a small sample size correction) for model selection and used cumulative variable weights $\left(w_{i}\right)$ and $\mathrm{AIC}_{\mathrm{c}}$ to identify most important covariates. First listed model is top model from which abundance estimates $(\mathrm{N})$ were derived. Because global model set is so small, all models are presented. Lowest $\mathrm{AIC}_{\mathrm{c}}$ value: 49.105.

\begin{tabular}{lccccc}
\hline \hline Model & $\Delta \mathrm{AIC}_{\mathrm{c}}$ & $w_{i}$ & $\begin{array}{c}\text { Model } \\
\text { Likelihood }\end{array}$ & $k$ & Deviance \\
\hline $\begin{array}{l}\mathrm{p} \text { (percent water on plot) } \\
\mathrm{N} \text { (plot) } \\
\mathrm{p} \text { (distance to wetland) }\end{array}$ & 0.000 & 0.620 & 1.000 & 3 & 42.894 \\
$\begin{array}{l}\mathrm{N} \text { (plot) } \\
\mathrm{p}(.)\end{array}$ & 1.714 & 0.263 & 0.424 & 3 & 44.608 \\
$\begin{array}{l}\mathrm{N} \text { (plot) } \\
\mathrm{p} \text { (habitat) }\end{array}$ & 5.397 & 0.042 & 0.067 & 2 & 50.397 \\
$\begin{array}{l}\mathrm{N} \text { (plot) } \\
\mathrm{p} \text { (elevation) } \\
\mathrm{N} \text { (plot) } \\
\mathrm{p} \text { (percent scrub canopy) }\end{array}$ & 7.484 & 0.015 & 0.024 & 3 & 50.379 \\
$\mathrm{~N}$ (plot) & 5.705 & 0.036 & 0.058 & 4 & 46.456 \\
\hline
\end{tabular}

Lesser Yellowlegs abundances were calculated using the model $\mathrm{p}_{\text {percent water on plot }} \mathrm{N}_{\text {plot }}$. Percent water on plot had a weak negative relationship with detection $(\beta=-0.132 \pm 0.059)$ and average detection probability for Lesser Yellowlegs was $0.752 \pm 0.132$. Estimated number of Lesser Yellowlegs on occupied plots ranged from one to seven birds. Extrapolated to the entire sampling frame, in 2017, estimated abundance of Lesser Yellowlegs was $12,478 \pm 6494$ individuals (Table 3 ). 
Table 3. Lesser Yellowlegs (Tringa flavipes) abundance estimates \pm standard error (SE) for 2017 on military lands in interior Alaska.

\begin{tabular}{lccc}
\hline \hline Strata & Average Number per Plot & Average Density (per ha) & Total Abundance \\
\hline Tanana Flats Training Area River & $0.905 \pm 0.085$ & $0.057 \pm 0.005$ & $510 \pm 329$ \\
Tanana Flats Training Area Lowland & $1.015 \pm 0.059$ & $0.063 \pm 0.004$ & $11,864 \pm 6098$ \\
Donnelly Training Area East & $0.107 \pm 0.011$ & $0.007 \pm 0.001$ & $104 \pm 71$ \\
Donnelly Training Area West & $0.000 \pm 0.004$ & $0.000 \pm 0.000$ & 0 \\
Total & & & $12,478 \pm 6494$ \\
\hline
\end{tabular}

Variance components analysis suggests that distance to wetland explains the most variation in Lesser Yellowlegs plot-level abundance $(20.37 \%)$, followed by percent scrub canopy cover (9.24\%), and Viereck habitat classification (6.55\%; Table 4).

\section{Lesser Yellowlegs habitat use model results}

Variables retained from step one for further habitat use modeling (i.e., those with $w_{i} \geq 0.50$ ) were elevation, percent scrub canopy cover, and year. For colonization, retained variables from step one of model selection were elevation, forb/lichen/herbaceous, and distance to wetland. For detection, retained variables were percent scrub canopy cover, percent water on plot, scrub Viereck classification, and visit (for full tables see Martin 2019).

In the second step of model selection, we analyzed all possible combinations of covariates retained from the first step of model selection. Variables with $w_{i} \geq 0.50$ for habitat use in the final analysis were elevation $\left(w_{i}=0.914\right)$ and percent scrub canopy cover $\left(w_{i}=0.838\right)$. Colonization had no variables with $w_{i} \geq 0.50$. For detection, percent water on plot $\left(w_{i}=0.754\right)$, scrub Viereck classification $\left(w_{i}=0.534\right)$, and visit $\left(w_{i}=0.582\right)$ were the top predictor variables (Table 5; for full tables see Martin 2019).

Use estimates for Lesser Yellowlegs decreased as elevation increased (Fig. 2a; $\beta=-0.010 \pm 0.003$ ) and decreased as percent scrub canopy increased (Fig. 2b; $\beta=-0.076, \pm 0.031$ ). We estimated colonization probability as $0.159 \pm 0.002$. The derived estimate of extinction was zero. Only two plots out of 29 that had birds detected in 2016 had no detections in 2017 . To confirm our extinction estimate, we re-ran the model with a derived colonization estimate and a direct estimate of extinction. The estimate of extinction remained zero in this model.

Across years, detection was higher during visit one than during visit two (visit one $p=0.390 \pm 0.086$, visit two $p=0.228 \pm 0.063$ ). Detection estimates for Lesser Yellowlegs increased as percent water on plot increased $(\beta=0.039 \pm 0.012)$ and increased when the dominant vegetation type on plot was scrub (with scrub $\mathrm{p}=$ $0.558 \pm 0.109$; without scrub $\mathrm{p}=0.240 \pm 0.075$ ).

\section{DISCUSSION}

\section{Abundance estimation}

Our results begin to address the data deficiencies identified by the Alaska shorebird conservation plan (Alaska Shorebird Group 2019) and the Alaska Center for Conservation Science species ranking system. We provide the first abundance estimates in the interior boreal forest and reconfirm habitat associations for this species. Based on current continental population estimates, military lands in interior Alaska support $8 \%(5.83 \%-9.62 \%)$ of all Lesser Yellowlegs estimated to breed in Alaska. As predicted, lowland strata (TFTA River and TFTA Lowland) had higher abundances of Lesser Yellowlegs (12,374 combined) than upland strata (104 combined). Previous surveys, inventories, and anecdotal evidence on or near the study site found frequent occurrence of lowland birds such as Lesser Yellowlegs using the lowland habitats of the boreal forest (Handel and Sauer 2017; J. Mason, personal communication). Our results, based on a rigorous sampling design, support this relationship, and are a reasonable estimate given the number of Lesser Yellowlegs estimated to breed in Alaska (24\% of between 400,000 and 660,000 Lesser Yellowlegs; Alaska Shorebird Group 2019). Our results either suggest that the military lands in interior Alaska support a higher abundance of Lesser Yellowlegs than other areas in the boreal forest, or that the current continental population estimate for Lesser Yellowlegs is too low.

Fig. 2. Probability of habitat use for Lesser Yellowlegs (Tringa flavipes) decreased as elevation increased (2a) and decreased as percent scrub canopy cover increased (2b). 95\% confidence intervals shown.
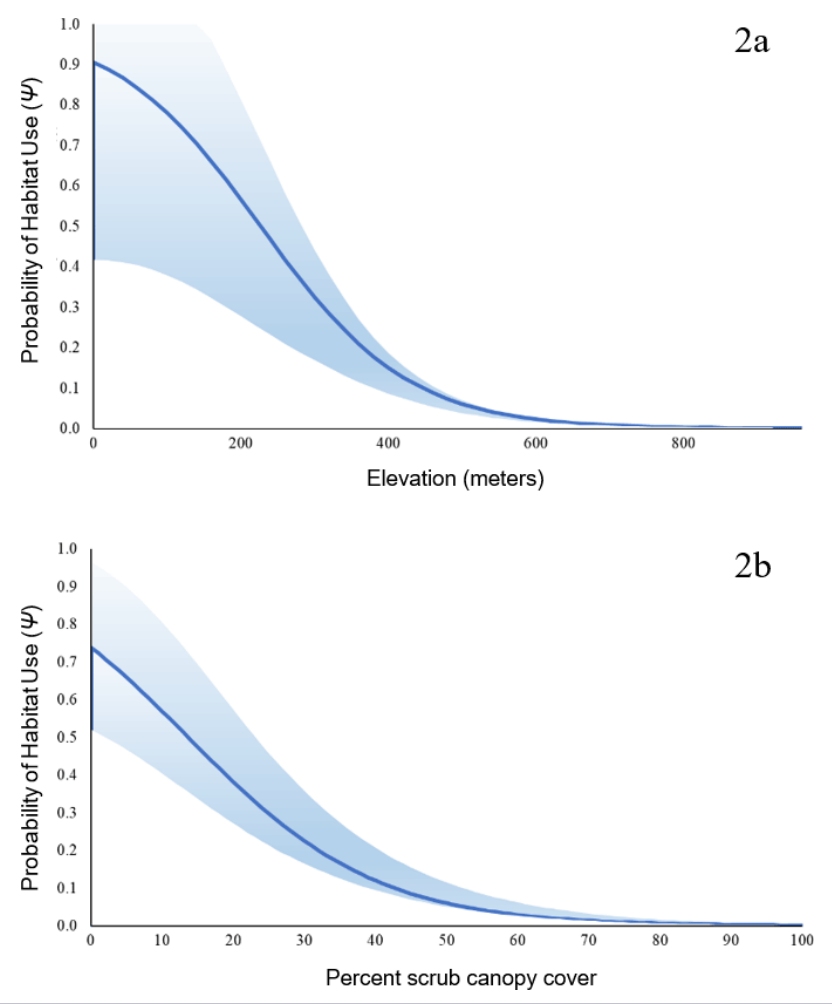
Table 4. The variation in Lesser Yellowlegs (Tringa flavipes) abundance $\left(\sigma^{2}\right)$ explained by each habitat covariate and corresponding standard errors (SE) are presented from variance components analysis in Program MARK. Beta $(\beta)$ estimates explain relationships between abundance and habitat covariates. Upper and lower $95 \%$ confidence limits $(C L)$ presented. No positive variance was explained by percent water on plot or elevation and is designated with $\mathrm{a}$ *.

\begin{tabular}{lccccc}
\hline \hline Habitat Covariate & $\sigma^{2}$ & $\begin{array}{c}\text { Lower } 95 \% \\
\text { CL }\end{array}$ & $\begin{array}{c}\text { Upper 95\% } \\
\text { CL }\end{array}$ & $\beta \pm$ SE & $\begin{array}{c}\text { Percent Variance } \\
\text { Explained }\end{array}$ \\
\hline Intercept model & 3.823 & 2.095 & 8.867 & $3.137 \pm 0.513$ & -- \\
Distance to wetland & 3.045 & 1.644 & 7.280 & $-0.003 \pm 0.001$ & 20.371 \\
Percent scrub canopy & 3.470 & 1.884 & 8.214 & $-0.032 \pm 0.019$ & 9.249 \\
Habitat & 3.573 & 1.866 & 8.960 & & 6.554 \\
$\quad$ Forest & & & & $0.767 \pm 1.802$ & \\
$\quad$ Scrub & 3.930 & 2.144 & 9.266 & $0.049 \pm 0.067$ & $*$ \\
Percent water on plot & 4.001 & 2.165 & 9.532 & $-0.002 \pm 0.004$ & $*$ \\
Elevation & & & & & \\
\hline
\end{tabular}

Table 5. Cumulative Akaike's Information Criterion (with a small sample size correction; $\left.\mathrm{AIC}_{\mathrm{c}}\right)$ weights for covariates $\left(w_{i}\right)$ analyzed in step two of model selection for Lesser Yellowlegs (Tringa flavipes) habitat use $(\psi)$, colonization $(\gamma)$, and detection probability (p). Extinction ( $\varepsilon$ ) was derived. We relied upon $\mathrm{AIC}_{\mathrm{c}}$ for model selection and used $w_{i}$ to identify most important covariates. Covariates retained for second step of model selection had $w_{i} \geq 0.50$. Covariates for which we had no hypotheses for a particular parameter are noted with NA (Not Applicable).

\begin{tabular}{lccc}
\hline \hline Covariate & $\begin{array}{c}\text { Habitat Use } \\
(\psi) w_{i}\end{array}$ & $\begin{array}{c}\text { Colonization } \\
(\gamma) w_{i}\end{array}$ & $\begin{array}{c}\text { Detection } \\
(p) w_{i}\end{array}$ \\
\hline Elevation & 0.914 & 0.387 & NA \\
Percent scrub canopy & 0.838 & 0.001 & 0.241 \\
Percent water on plot & NA & NA & 0.754 \\
Distance to wetland & NA & 0.173 & NA \\
Forest & NA & NA & NA \\
Scrub & NA & NA & 0.534 \\
Forb/lichen/herbaceous & NA & 0.344 & NA \\
Visit & NA & NA & 0.582 \\
Year & 0.002 & NA & NA \\
Year*Visit & NA & NA & NA \\
\hline
\end{tabular}

The power to extrapolate results from our study site on military lands to the entirety of BCR 4 depends on how representative our study site is of habitat typically found in the BCR. Because of its sheer size, latitudinal and elevational span, the composition of the entire BCR 4 is unlikely to resemble our study site that is just $0.69 \%$ of the BCR. Our estimate that $8 \%(5.83 \%-9.62 \%)$ of Lesser Yellowlegs breeding in Alaska occur in an area that makes up less than $1 \%$ of the BCR indicates that there are pockets of suitable and unsuitable habitat, and the ratio of suitable to unsuitable habitat is most likely different when the entire BCR is considered.

Variation in plot-level abundance was best explained by distance to wetland $(20.3 \%)$, percent scrub canopy cover $(9.2 \%)$, and habitat classification (6.5\%). Abundance was positively related to distance to wetland. We note that much of BCR 4 is classified as wetland habitat.

\section{Habitat use}

More research has been conducted on shorebird habitat use during migration at lower latitudes than on breeding grounds in
Alaska (e.g., Webb et al. 2010). We found many of the same habitat variables that dictate migration stopover site selection and informed initial hypotheses (e.g., vegetation height, shrub cover, proximity to wetlands, and wetland size) are also important determinants in Lesser Yellowlegs breeding site use (Steen et al. 2018). Critical habitat associations confirmed in this study are mostly contained within state and federally managed lands in BCR 4 (Alaska Shorebird Group 2019).

Elevation was a top predictor variable, and negatively correlated with habitat use by Lesser Yellowlegs. This result is consistent with current knowledge about lowland shorebird use of habitat across North America (Gillespie and Fontaine 2017). Lowland shorebirds, including Lesser Yellowlegs, are often associated with river corridors, which are more often found at low elevations $(<$ $600 \mathrm{~m}$ ) on both Tanana Flats Training Area and Donnelly Training Area. These birds are suspected to use lower habitat areas that retain water and support food resources (Skagen and Knopf 1994).

Percent scrub canopy cover was a top predictor variable and negatively correlated with Lesser Yellowlegs habitat use. As climate change progresses, a change from lowland graminoid habitats to more shrub dominated habitats is projected (Sturm et al. 2005, Elmendorf et al. 2012). This "greening" projection results in less suitable breeding habitat for lowland shorebirds, especially for species using lowland graminoid habitats (i.e., low percent scrub canopy cover). This greening trend could potentially extend the distances required for lowland shorebirds to migrate to suitable breeding habitats.

Lesser Yellowlegs detection increased in habitats dominated by scrub vegetation. We predicted the opposite relationship and thought denser shrub habitat provided more cryptic ground covering for nests than other habitat types (e.g., forb/herbaceous or barren ground) and observers would be less likely to see the birds when nesting. One explanation for our result is that on a plot with dominant scrub, Lesser Yellowlegs were more likely to be perched or flying, making them more obvious for detection.

\section{CONCLUSION}

In this study we begin to understand the habitat types within BCR 4 that are most likely to be occupied by breeding Lesser Yellowlegs and we extrapolate plot-level habitat use and abundance estimates to the larger study site. The next step in extrapolation of these 
estimates to the entire BCR would be analyzing the role of important covariates identified in this study, e.g., low elevation and low percent scrub cover, throughout the BCR.

The conservation status of Lesser Yellowlegs is inconsistent among international organizations, e.g., IUCN Red List data and NatureServe, and federal or state organizations, e.g., U.S. Fish and Wildlife Service and State of Alaska. The Lesser Yellowlegs decline in recent decades is cause for alarm and an impetus to reevaluate Lesser Yellowlegs' classifications at both a local and international scale. Some important migratory and wintering sites are protected, many through the Western Hemisphere Shorebird Reserve Network, but breeding sites like the interior boreal forest of Alaska support relatively high numbers of Lesser Yellowlegs and have no protected status (Clay et al. 2012, Tibbitts and Moskoff 2020). We believe further focus on such breeding areas is warranted.

Responses to this article can be read online at: https://www.ace-eco.org/issues/responses.php/2012

\section{Author Contributions:}

ECM, KAJ, and PFD designed the surveys. KAJ, PFD, and CFB supervised research. ECM wrote the manuscript with substantial edits from PFD and KAJ. ECM and PFD analyzed the data. CFB contributed substantial resources and funding.

\section{Acknowledgments:}

K. E. Shockley and W. L. Kendall offered valuable suggestions and thought-provoking considerations throughout the research process. Thank you to the many wildife technicians and scientists who collected data: L. B. Williams, J. S. Pelham, G. J. Greenwood, C. R. White, N. O. Castellano, L. K. Grevstad, K. B. Testerman, E. M. Fotter, K. Crowley, K. Van Atta, D. Jenkins, S. Debruyne, and A. Davis. J. Haddix was instrumental in acquiring funding for this project. Funding for this project was provided by the USAG Alaska, Fort Wainwright, Task Order Numbers 15-2-0058 (SOW 15-35) and 14-2-0065 (SOW 14-25). These methods were carried out under the Institutional Animal Care and Use Committee (IACUC) Exemption \#2016-10.

\section{LITERATURE CITED}

Akaike, H. 1974. A new look at the statistical model identification. IEEE Transactions on Automatic Control. 19(6):716-723. https:// doi.org/10.1109/TAC.1974.1100705

Alaska Shorebird Group. 2008. Alaska shorebird conservation plan: version II. Alaska Shorebird Group, Anchorage, Alaska, USA.

Alaska Shorebird Group. 2019. Alaska shorebird conservation plan: version III. Alaska Shorebird Group, Anchorage, Alaska, USA. [online] URL: https://www.shorebirdplan.org/wp-content/ uploads/2019/05/AlaskaPlanExecSum2019.pdf
Andres, B. A., J. A. Johnson, S. C. Brown, and R. B. Lanctot. 2016. Shorebirds breed in unusually high densities in the Teshekpuk Lake Special Area, Alaska. Arctic 65:411-420. https:// doi.org/10.14430/arctic4239

Andres, B. A., P. A. Smith, R. I. G. Morrison, C. L. Gratto-Trevor, S. C. Brown, and C. A. Friis. 2012. Population estimates of North American shorebirds, 2012. Wader Study Group Bulletin 119 (3):178-194. [online] URL: https://www.shorebirdplan.org/wpcontent/uploads/2013/03/ShorePopulationAndresEtA12012.pdf

Barbieri, M., and J. Berger. 2004. Optimal predictive model selection. Annals of Statistics 32(3):870-897. https://doi. org/10.1214/009053604000000238

Bart, J. R., B. Andres, S. Brown, G. Donaldson, B. Harrington, V. Johnston, S. Jones, G. Morrison, and S. Skagen. 2005. The program for regional and international shorebird monitoring (PRISM). U.S. Shorebird Conservation Partnership. General Technical Report 893-901. U.S. Forest Service, Albany, California, USA. [online] URL: https://pubs.er.usgs.gov/ publication/2002060

Bled, F., J. A. Royle, and E. Cam. 2011. Assessing hypotheses about nesting site occupancy dynamics. Ecology 92(4):938-951. https://doi.org/10.1890/10-0392.1

Bowden, D. C., G. C. White, A. B. Franklin, and J. L. Ganey. 2003. Estimating population size with correlated estimates. Journal of Wildlife Management 67(1):1-10. [online] URL: https://www.fs.fed.us/rm/pubs_other/rmrs_2003_ganey_j002.pdf

Bromaghin, J. F., T. L. McDonald, and S. C. Amstrup. 2013. Plausible combinations: an improved method to evaluate the covariate structure of Cormack-Jolly-Seber mark-recapture models. Open Journal of Ecology 3(1):11-22. https://doi. org/10.4236/oje.2013.31002

Burnham, K. P., and D. R. Anderson. 2002. Model selection and multimodel inference: a practical information-theoretical approach. Second edition. Springer-Verlag, New York, New York, USA.

Butcher, G. S., and D. K. Niven. 2007. Combining data from the Christmas bird count and the breeding bird survey to determine the continental status and trends of North American birds. National Audubon Society, New York, New York, USA.

Center for Environmental Management of Military Lands. 1999. Alaska Army Lands Withdrawal Renewal. Public Law 106-65 Section 3011, in Military Land Withdrawal Act of 1999. Office of the Federal Register, National Archives and Records Administration, Washington, D.C., USA. [online] URL: https:// home.army.mil/alaska/application/files/5815/0948/7270/ Public_Law_106-65_Section_3011.pdf

Clay, R. P., A. J. Lesterhuis, and S. Centrón. 2012. Conservation plan for the Lesser Yellowlegs (Tringa flavipes), version 1.0. Manomet Center for Conservation Sciences, Manomet, Massachusetts, USA. [online] URL: https://whsrn.org/wpcontent/uploads/2019/02/conservationplan_leye_v1.0_2012.pdf

Cooch, E., and G. White. 2013. Program MARK: a gentle introduction. [online] URL: http://www.nativefishlab.net/library/ internalpdf/21294.pdf 
Doherty, P. F., K. P. Burnham, and G. C. White. 2012. Comparison of model building and selection strategies. Journal of Ornithology 152:317-323. https://doi.org/10.1007/s10336-010-0598-5

Elmendorf, S. C., G. H. R. Henry, R. D. Hollister, R. G. Björk, A. D. Bjorkman, T. V. Callaghan, L. S. Collier, E. J. Cooper, J. H. C. Cornelissen, T. A. Day, A. M. Fosaa, W. A. Gould, J. Grétarsdóttir, J. Harte, L. Hermanutz, D. S. Hik, A. Hofaardg, F. Jarrad, I. Jonsdottir, F. Keuper, K. Klanderud, J. Klein, S. Koh, G. Kudo, S. I. Lang, V. Loewen, J. L. May, J. Mercado, A. Michaelsen, U. Molau, I. H. Myers-Smith, S. Oberbauer, S. Pieper, E. Post, C. Rixen, C. Robinson, N. Schmidt, G. Shaver, A. Stenstrom, A. Tolvanen, O. Totland, T. Troxler, C. Wahren, P. Webber, J. Welker, and P. Wookey. 2012. Global assessment of experimental climate warming on tundra vegetation: heterogeneity over space and time. Ecology Letters 15(2):164-175. https://doi.org/10.1111/j.1461-0248.2011.01716.x

Elphick, C. S., and T. L. Tibbits. 1998. Greater Yellowlegs (Tringa melanoleuca), version 2.0. In A. F. Poole and F. B. Gill, editors. The Birds of North America. Cornell Lab of Ornithology, Ithaca, New York, USA. https://doi.org/10.2173/bna.355

Environmental Systems Research Institute (ESRI). 2011. ArcGIS Desktop: Release 10. Environmental Systems Research Institute, Redlands, California, USA.

Gallant, A. L., E. F. Binnian, J. M. Omernik, and M. B. Shasby. 1995. Ecoregions of Alaska. U.S. Geological Survey Professional Paper 1567.73. https://doi.org/10.3133/pp1567

Gillespie, C. R., and J. J. Fontaine. 2017. Shorebird stopover habitat decisions in a changing landscape. Journal of Wildlife Management 81(6):1051-1062. https://doi.org/10.1002/jwmg.21271

Handel, C. M., and J. R. Sauer. 2017. Combined analysis of roadside and off-road breeding bird survey data to assess population change in Alaska. Condor 119(3):557-575. https://doi. org/10.1650/CONDOR-17-67.1

Huggins, R. M. 1989. On the statistical analysis of capture experiments. Biometrika 76(1):133-140. https://doi.org/10.1093/ biomet/76.1.133

Huggins, R. M. 1991. Some practical aspects of a conditional likelihood approach to capture experiments. International Biometric Society 47(2):725-732. https://doi.org/10.2307/2532158

Kessel, B., and D. Gibson. 1978. Status and distribution of Alaska birds. Studies in Avian Biology No. 1. Allen Press, Inc., Lawrence, Kansas, USA.

Lebreton J. D., K. P. Burnham, J. Clobert, and D. R. Anderson. 1992. Modeling survival and testing biological hypotheses using marked animals - a unified approach with case-studies. Ecological Monographs 62(1):67-118. https://doi.org/10.2307/2937171

Lindström, Å., M. Green, M. Husby, J. A. Kålås, and A. Lehikoinen. 2015. Large-scale monitoring of waders on their boreal and Arctic breeding grounds in Northern Europe. Ardea 103(1):3-15. https://doi.org/10.5253/arde.v103i1.a1

MacKenzie, D. I., J. Nichols, J. Royle, K. Pollock, L. Bailey, and J. Hines. 2017. Occupancy estimation and modeling. Academic Press, Cambridge, Massachusetts, USA.
Martin, E. C. 2019. Shorebird habitat use and abundance estimates on military lands in interior Alaska. Thesis. Colorado State University, Fort Collins, Colorado, USA. [online] URL: https://mountainscholar.org/bitstream/handle/10217/195303/ Martin_colostate_0053N_15341.pdf

Martin, E. C., P. F. Doherty, Jr, K. A. Jochum, and C. F. Bagley. 2020. Shorebird abundance estimates in interior Alaska. Journal of Wildlife Management 84(7):1283-1295. https://doi.org/10.1002/ jwmg. 21913

Morrison, R. I. G., B. J. McCaffery, R. E. Gill, S. K. Skagen, S. L. Jones, G. W. Page, C. L. Gratto-Trevor, and B. A. Andres. 2006. Population estimates of North American shorebirds. Wader Study Group Bulletin 111:67-85. [online] URL: https://www. waderstudygroup.org/article/3068/

Nichols, J. D., J. E. Hines, J. R. Sauer, F. W. Fallon, J. E. Fallon, and P. J. Heglund. 2000. A double-observer approach for estimating detection probability and abundance from point counts. Auk 117(2):393-408. https://doi.org/10.1093/auk/117.2.393

North American Bird Conservation Initiative (NABCI). [date unknown]. What are the primary purposes of BCRs? U.S. NABCI, Washington, D.C., USA. [online] URL: https://nabcius.org/resources/bird-conservation-regions/

Parmesan, C. 2007. Influences of species, latitudes and methodologies on estimates of phenological response to global warming. Global Change Biology 13(9):1860-1872. https://doi. org/10.1111/j.1365-2486.2007.01404.x

Pearson, R. G., S. J. Phillips, M. M. Loranty, P. S. A. Beck, T. Damoulas, S. J. Knight, and S. J. Goetz. 2013. Shifts in Arctic vegetation and associated feedbacks under climate change. Nature Climate Change 3:673-677. https://doi.org/10.1038/ nclimate 1858

Post, E., M. Forchhammer, M. Bret-Harte, T. Callaghan, T. Christensen, B. Elberling, A. Fox, O. Gilg, D. Hik, T. Høye, R. Ims, E. Jeppesen, D. Klein, J. Madsen, A. McGuire, S. Rysgaard, D. Schindler, I. Stirling, M. Tamstorf, N. Tyler, R. van der Wal, J. Welker, P. Wookey, N. Schmidt, and P. Aastrup. 2009. Ecological dynamics across the Arctic associated with recent climate change. Science 325:1355-1358. https://doi.org/10.1126/science.1173113

Roach, J., B. Griffith, D. Verbyla, and J. Jones. 2011. Mechanisms influencing changes in lake area in Alaskan boreal forest. Global Change Biology 17(8):2567-2583. https://doi.org/10.1111/ j.1365-2486.2011.02446.x

Sauer, J. R., D. K. Niven, J. E. Hines, D. J. Ziolkowski, Jr, K. L. Pardieck, J. E. Fallon, and W. A. Link. 2017. The North American breeding bird survey, results and analysis 1966-2015, version 2.07.2017. U.S. Geological Survey, Patuxent Wildlife Research Center, Laurel, Maryland, USA. [online] URL: https://www.mbrpwrc.usgs.gov/bbs/

Sauer, J. R., W. A. Link, and J. E. Hines. 2020. The North American breeding bird durvey, analysis results 1966-2018: U.S. Geological Survey data release. U.S. Geological Survey, Reston, Virginia, USA. https://doi.org/10.5066/P9TQI68U

Skagen, S. K. 2006. Migration stopovers and the conservation of Arctic-breeding Calidridine sandpipers. Auk 123(2):313-322. https://doi.org/10.1093/auk/123.2.313 
Skagen, S. K., J. Bart, B. Andres, S. Brown, G. Donaldson, B. Harrington, V. Johnston, S. L. Jones, and R. I. G. Morrison. 2003. Monitoring the shorebirds of North America: towards a unified approach. Wader Study Group Bulletin 100:102-104.

Skagen, S., and F. Knopf. 1994. Migrating shorebirds and habitat dynamics at a prairie wetland complex. Wilson Bulletin 106 (1):91-105. [online] URL: https://sora.unm.edu/sites/default/ files/journals/wilson/v106n01/p0091-p0105.pdf

Steen, V., S. Skagen, and B. Noon. 2018. Preparing for an uncertain future: migrating shorebird response to past climatic fluctuations in the Prairie Potholes. Ecosphere 9(2):e02095. https://doi.org/10.1002/ecs2.2095

Stein, B. A., C. Scott, and N. Benton. 2008. Federal lands and endangered species: the role of military and other federal lands in sustaining biodiversity. BioScience 58(4):339-347. https://doi. org/10.1641/B580409

Stevens, D. L., and A. R. Olsen. 2004. Spatially balanced sampling of natural resources. Journal of the American Statistical Association 99(465):262-278. https://doi.org/10.1198/016214504000000250

Sturm, M., J. Schimel, G. Michaelson, J. M. Welker, S. F. Oberbauer, G. E. Liston, J. Fahnestock, and E. Vladimir. 2005. Winter biological processes could help convert Arctic tundra to shrubland. BioScience 55(1):17-26. https://doi.org/10.1641/0006-3568 (2005)055[0017:WBPCHC]2.0.CO;2

Swift, R., A. Rodewald, and N. Senner. 2017. Breeding habitat of a declining shorebird in a changing environment. Polar Biology 40:1777-1786. https://doi.org/10.1007/s00300-017-2101-8

Taft, O. W., and S. M. Haig. 2006. Importance of wetland landscape structure to shorebirds wintering in an agricultural valley. Landscape Ecology 21:169-184. https://doi.org/10.1007/ s10980-005-0146-5

Theobald, D. M., D. L. Stevens, D. White, N. S. Urquhart, A. R. Olsen, and J. B. Norman. 2007. Using GIS to generate spatially balanced random survey designs for natural resource applications. Environmental Management 40:134-146. https:// doi.org/10.1007/s00267-005-0199-x

Tibbitts, T. L., and W. Moskoff. 1999. Lesser Yellowlegs (Tringa flavipes). A. Poole and F. Gill, editors. The Birds of North America. Academy of Natural Sciences, Philadelphia, Pennsylvania, USA, and The American Ornithologists' Union, Washington, D.C., USA.

Tibbitts, T. L., and W. Moskoff. 2020. Lesser Yellowlegs (Tringa flavipes), version 1.0. In A. F. Poole, editor. Birds of the world. Cornell Lab of Ornithology, Ithaca, New York, USA. https://doi. org/10.2173/bow.lesyel.01

U.S. Army Garrison Fort Wainwright. 2013. Fort Wainwright (FWA) integrated natural resource management plan. U.S.
Department of Defense, Arlington, Virginia, USA. [online] URL: https://home.army.mil/alaska/application/files/1815/0939/5912/ FWA_INRMP_2013_Update_6-4-13_reduced.pdf

U.S. Fish and Wildlife Service. 1918. Migratory bird treaty act of 1918. Digest of federal resource laws of interest to the U.S. Fish and Wildlife Service. U.S. Fish and Wildlife Service, Bailey's Crossroads, Virginia, USA. [online] URL: https://www.fws.gov/ laws/lawsdigest/migtrea.html

U.S. Shorebird Conservation Plan Partnership (USSCPP). 2016. Shorebirds of conservation concern in the United States of America 2016. U.S. Fish and Wildlife Service, Division of Migratory Bird Management, Lakewood, Colorado, USA. [online] URL: https://www.shorebirdplan.org/wp-content/uploads/2016/08/ Shorebirds-Conservation-Concern-2016.pdf

Viereck, L. A., C. T. Dyrness, A. R. Batten, and K. J. Wenzlick. 1992. The Alaska vegetation classification. USDA General Technical Report. U.S. Department of Agriculture, Forest Service, Pacific Northwest Research Station, Portland, Oregon, USA. https://doi.org/10.2737/PNW-GTR-286

Viereck, L., D. T. Dyrness, and M. J. Foote. 1993. An overview of the vegetation and soils of the floodplain ecosystems of the Tanana River, interior Alaska. Canadian Journal of Forest Research 23(5):889-898. https://doi.org/10.1139/x93-117

Watts, B. D., E. T. Reed, and C. Turrin. 2015. Estimating sustainable mortality limits for shorebirds using the Western Atlantic Flyway. Wader Study 122(1):37-53. https://doi. org/10.18194/ws.00005

Wauchope, H. S., J. D. Shaw, Ø. Varpe, E. G. Lappo, D. Boertmann, R. B. Lanctot, and R. A. Fuller. 2016. Rapid climatedriven loss of breeding habitat for Arctic migratory birds. Global Change Biology 23(3):1085-1094. https://doi.org/10.1111/ gcb.13404

Webb, E. B., L. Smith, M. Vrtiska, and T. Lagrange. 2010. Effects of local and landscape variables on wetland bird habitat use during migration through the rainwater basin. Journal of Wildlife Management 74(1):109-119. https://doi.org/10.2193/2008-577

White, G. C., and K. P. Burnham. 1999. Program MARK: survival estimation from populations of marked animals. Bird Study 46: S120-S139. https://doi.org/10.1080/00063659909477239

Williams, B. K., J. D. Nichols, and M. J. Conroy. 2002. Analysis and management of animal populations. Academic, New York, New York, USA.
Editor-in-Chief: Keith A.Hobson

Subject Editor: Erica Nol
Sponsored by the Society of Canadian Ornithologists and Birds Canada Parrainée par la Société des ornithologistes du Canada et Oiseaux Canada

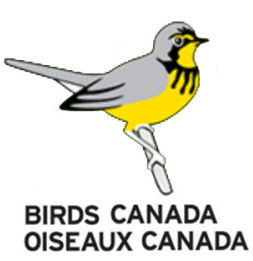

